\title{
PERALATAN DAPUR DALAM BAHASA KARO \\ KAJIAN METABAHASA SEMANTIK ALAMI
}

\author{
Hariati Br Sembiring(sembiringhariati22@mail.com) \\ Mulyadi (mulyadi.usu@gmail.com) \\ Unversitas Sumatera Utara
}

\begin{abstract}
ABSTRAK
Penelitian ini mendeskripsikan kategorisasi dan makna peralatan dapur dalam bahasa Karo. Data yang digunakan adalah data lisan, data tulis, dan data intuitif.Data dikumpulkan dengan menggunakan metode cakap dan metode simak.kemudian, data dianalisis dengan metode agih dan hasilnya disajikan dengan metode formal dan informal.Teori yang digunakan adalah teori metabahasa semantik alami. Hasil penelitian menunjukkan bahwa peralatan dapur dalam bahasa Karo dikategorisasikan menjadi dua. Pertama peralatan dapur yang digunakan untuk mengolah makanan/minuman ('benda [M] ini ada karena seseorang ingin mengolah makanan/minuman [M]'). Kedua peralatan dapur yang digunakan untuk menyimpan makanan, air, dan peralatan masak ('benda [M] ini ada karena seseorang ingin menyimpan makanan/ minuman/ peralatan masak [M]'). Selanjutnya, makna peralatan dapur dibentuk oleh elemen makna asali SESUATU, KARENA, SESEORANG, ADA, INGIN, dan MELAKUKAN. dari elemen makna asali tersebut terbentuklah struktur komponen semantis (a) salah satu jenis benda [M], (b) benda [M] ini ada karena seseorang membuatnya [M], (c) benda ini berukuran $[M]$....., (d) seseorang mengambilnya dengan satu atau dua tangan [M]. Peralatan dapur dalam bahasa Karo juga dibentuk oleh molekul molekul semantik yang berkombinasi membentuk sintaksis makna universal 'sesuatu ada karena seseorang ingin mengolah/menyimpan [M] sesuatu'.
\end{abstract}

Kata kunci: semantik primitif, polisemi, molekul semantik, sintaksis makna universal

\section{PENDAHULUAN}

Kosakata dalam sebuah bahasa dipengaruhioleh budaya penuturnya.Pola komunikasi biasanya dipengaruhi oleh kebudayaan yang ditelusuri melalui pengamatan terhadap kecenderungan berbahasa.Bahasa sangat dipengaruhi oleh kebudayaan yang terdapat dalam suatu masyarakat. Dalam pengertian lain, segala hal yang ada dalam kebudayaan akan tercermin di dalam bahasa. Salah satu budaya yang bersifat universal adalah budaya makan.Setiap orang memerlukan makanan yang diolah dengan peralatan dapur yang berbeda-beda sesuai dengan budaya masing-masing.Budaya makan ini juga dimiliki oleh masyarakat Karo dan dengan sendirinya mereka juga memiliki peralatan dapur yang beragam.Peralatan dapur yang terdapat pada masyarakat Karo bersumber dari peralatan dapur yang digunakan oleh nenek moyang mereka. Peralatan dapur tersebut dibuat oleh manusia dari bahan alam yang sangat sederhana dan unik. Peralatan dapur tersebut bermacam-macam sesuai dengan kebutuhan 
masyarakat ada peralatan dapur yang fungsinyasama, tetapi memiliki bahan dan bentuk yang berbeda. Semua jenis peralatan dapur yang dimiliki oleh setiap budaya dapat dikategorisasikan berdasarkan kesamaan semantisnya.

Peralatan dapur yang berada dalam kategori yang sama dapat memiliki perbedaan semantis yang sangat halus. Untuk memperlihatkan perbedaan semantis yang terdapat pada setiap butir leksikal peralatan dapur dianalisis dengan parafrase makna.Peralatan dapur dalam bahasa Karo dapat dikategorisasikan berdasarkan tempat, tujuan, penampilan, dan ukuran.Misalnya peralatan dapur yang memiliki tujuan untuk menyimpan makanan dan air, yaitu gumbar 'sejenis rantang dari bambu', tabu-tabu 'kendi', pinggan 'piring (kecil)', busan 'sejenis perian dari bambu' dan kandi-kandi 'bumbung.

Contoh:

(1) a. Itama nande lau $k u$ bas tabu-tabu/?gumbar.

prep taruh TG air prep dalam kandi/?sejenis rantang dari bambu.

'Ibu menaruh air ke dalam kendi/ ?sejenis rantang dari bambu'.

b. Itamanande sira ku bas ??tabu-tabu/gumbar.

prep taruh TG garam prep dalam ??kendi/ sejenis rantang dari bambu.

'Ibu menaruh garam ke dalam ??kendi/ sejenis rantang dari bambu'.

Dari contoh (1a) terlihat bahwa objeknya adalah air, sedangkan pada contoh (1b) objeknya adalah garam.Peralatan dapur dalam bahasa Karo memiliki fitur semantis khusus yang membedakan satu butir leksikal dengan butir leksikal yang lain. Perbedaan tersebut ditunjukkan dengan komponen semantis.Misalnya, kudin gelang-gelang 'periuk kuningan' dan kudin taneh 'periuk tanah' bersinonim dan kedua kata itu memiliki ciri semantis yang berbeda. Kudin gelang-gelang digunakan untuk memasak nasi, sedangkan kudin taneh digunakan untuk mengarsik ikan dan memasak sayur.Perhatikan contoh di bawah ini.

(1) a. Nangger nakan kaka salu kudingelang-gelang/?kudin taneh. AKT.masak nasi TG pakai periuk kuningan/?periuk tanah.

'Kakak memasak nasi dengan periuk kuningan/ ?periuk tanah'.

b. Nggulenurung kaka salu?kudin gelang-gelang/kudin taneh.

AKT masak ikan mas TG pakai ?periuk kuningan/ periuk tanah.

'Kakak memasak ikan emas dengan ?periuk kuningan/ periuk tanah'.

Hal yang sama juga terjadi pada sangkalen'talenan' dan lagan 'cobek'. Keduanya berfungsi sebagai alat untuk mengolah makanan, tetapi memiliki ciri semantis yang berbeda.Sangkalen 'talenan' biasanya digunakan sebagai alas untuk memotong sayur atau daging, sedangkan lagan 'cobek digunakan untuk menggiling bumbu masakan.Misalnya,

(1) a. Nggiling lacina kaka salu lagan/?sangkalen. 
AKT giling cabai TG pakai cobek/ ?talenan.

'Kakak menggiling cabai dengan cobek/ ?talenan'.

b. Motong daging kaka $i$ das ?lagan/sangkalen.

potong dagin TG Prep atas ?cobek/ talenan.

'Kakak memotong daging di atas talenan/ ?cobek'.

Penelitian terhadap nomina sudah sering dilakukan, seperti Nengah (2006) dalam artikelnya meneliti "Bahasa Bali Usia Anak-Anak Kajian Metabahasa Semantik Alami", Utami (2010) dalam tesisnya mengkaji "Sinonim Nomina dalam Bahasa Indonesia', Septiani (2011) dalam skripsinya meneliti "Tipe Semantis Komponen Makna Nomina Bahasa Indonesia dalam Analogi Cerpen Jakarta Kafe Karya Tatyana", Ardianta (2013) dalam skripsinya "Bahasa Jawa Usia Anak-Anak Kajian Metabahasa Semantik Alami”.Sejauh yang diketahui penulis penelitian terhadap nomina dalam kajian metabahasa semantik alami belum pernah dilakukan.

\section{KAJIAN TEORI}

Nomina merupakan kata yang merujuk pada nama seseorang, tempat, atau semua benda yang dibendakan. Semua bahasa di dunia memiliki kelas kata tersebut. Goodard juga berpandangan bahwa, "Noun classifiers can occur with ordinary nouns in a broad range of contexts. They are found in language from all parts of the world" (Goddard, 1998:302).Nomina tersebut secara semantik dapat dianalisis dengan menggunakan teori metabahasa semantik alami untuk menganalisis makna yang terdapat pada nomina tersebut secara spesifik dengan menggunakan perangkat makna asali.Asumsi dasar teori MSA bahwa makna kompleks dapat dideskripsikan dengan menggunakan konfigurasi elemen makna yang lebih sederhana sehingga tidak dapat diuraikan lagi.

Peralatan dapur dalam bahasa Karo dapat diuraikan dengan teori metabahasa semantik alami (MSA).Metabahasa semantik alami (MSA) bertujuan untuk menemukan konsep primitif yang bersifat universal dalam menganalisis komponen makna secara rici.Dalam analisis komponen makna dilakukan dengan teknik parafrase.Misalnya pada kategorisasi teori MSA berperan mengelompokkan butir leksikal peralatan dapur berdasarkan kesamaan ciri semantisnya. Seperti kuran 'perian', guci 'buyung', tambe 'perian', dan kandi$k a n d i$ 'bumbung' terdapat dalam ranah yang sama. Dalam menganalisis makna teori MSA berperan memperlihatkan ciri semantis yang membedakan butir leksikal yang satu dengan butir leksikal yang lain yang terdapat dalam kategori yang sama.Dalam mengkaji makna, teori MSA menggabungkan tradisi, filsafat, logika, dan tipologi (Wierzbicka, 1996:23).Teori MSA menemukan konsep primitive yang bersifat universal dan tidak terlepas dari makna asali, molekul semantik, polisemi, dan sintaksis makna universal.

Pertama, makna asali(semantik primitif) adalah makna yang tidak dapat diuraikan lagi atau seperangkat makna yang tidak dapat berubah yang diwarisi oleh seseorang sejak lahir. Makna asali merupakan refleksi dan pembentukan 
pikiran yang dapat dieksplikasi dari bahasa alamiah (ordinary language) yang merupakan satu-satunya cara dalam merepresentasikan makna (Wierzbicka, 1996: 31). Makna asali menerangkan makna kompleks menjadi makna yang lebih sederhana tanpa harus berputar-putar (Wierzbicka, 1996: 12 dan Goddard, 1994: 2).Goddard mencatat ada 63 perangkat makna asali.Perangkat makna tersebut tampak pada tabel di bawah ini.

Tabel 1

Perangkat Makna Asali (Semantik Primitif) dalam Bahasa Indonesia

\begin{tabular}{|l|l|}
\hline Komponen & Elemen Makna Asali (Semantik Primitif) \\
\hline Substantif & $\begin{array}{l}\text { AKU, KAMU, SESEORANG/ORANG, SESUATU/ HAL, } \\
\text { TUBUH }\end{array}$ \\
\hline $\begin{array}{l}\text { Substantif } \\
\text { relasional }\end{array}$ & JENIS, BAGIAN \\
\hline Pewatas & INI, SAMA, LAIN \\
\hline Penjumlah & SATU, DUA, SEMUA, BANYAK, BEBERAPA \\
\hline Evaluator & BAIK, BURUK \\
\hline Deskriptor & BESAR, KECIL \\
\hline Predikat mental & PIKIR, TAHU, INGIN, RASA, LIHAT, DENGAR \\
\hline Ujaran & UJAR, KATA, BENAR \\
\hline $\begin{array}{l}\text { Tindakan, } \\
\text { peristiwa, } \\
\text { gerakan, } \\
\text { perkenaan }\end{array}$ & LAKU, TERJADI, GERAK, SENTUH \\
\hline $\begin{array}{l}\text { Keberadaan dan } \\
\text { milik }\end{array}$ & ADA, PUNYA \\
\hline Hidup dan mati & HIDUP, MATI \\
\hline $\begin{array}{l}\text { Waktu } \\
\text { BILA/WAKTU, SEKARANG, SEBELUM, SETELAH, LAMA, }\end{array}$ \\
\hline $\begin{array}{l}\text { Ruang } \\
\text { SEKEJAP, SEBENTAR, SEKARANG, SAAT }\end{array}$ \\
\hline Jonsep logis \\
JAUH, DEKAT, SEBELAH, DALAM \\
\hline $\begin{array}{l}\text { Augmentor, } \\
\text { intensifier }\end{array}$ & SIDAK, MUNGKIN, DAPAT, KARENA, JIKA \\
\hline Kesamaan & SEPERTI \\
\hline
\end{tabular}

Kedua, molekul semantik ialah makna leksikal kompleks.Dalam molekul semantik makna leksikal kompleks berfungsi sebagai unit semantik.Dalam hal ini kita mengikuti praktik metabahasa semantik alami (MSA) yang mencoba mendorong generalisasi tentang struktur semantik secara empiris, tetapi kita harus membatasi diri untuk penjelasan yang parsial (Goddard, 1998: 3). Hal ini mengikuti pola semantik, yaitu (a) kategori dalam hirearki taksonomi, (b) habitat, (c) ukuran, (d) penampilan, (e) perilaku, dan (f) hubungan dengan manusia. Molekul semanik diberi notasi [M] dalam eksplikasi.Berikut ini adalah tabel daftar molekul sementara yang ditunjukkan oleh (Goddard, 2010 dan Niputu, 2015). 
Tabel 2

Molekul Semantik

\begin{tabular}{|l|l|}
\hline $\begin{array}{l}\text { Body-part and } \\
\text { product }\end{array}$ & $\begin{array}{l}\text { Hands, mouth, eyes, ears, nose, face, legs, teeth, fingers, } \\
\text { fingernails, breasts, skin, blood, poo }\end{array}$ \\
\hline $\begin{array}{l}\text { Social categories } \\
\text { and family }\end{array}$ & $\begin{array}{l}\text { Children, men, women, mother, father, wife, husband, be } \\
\text { born }\end{array}$ \\
\hline Physical & Hard, long, round, flat, sharp, heavy, thick, thin, smooth \\
\hline $\begin{array}{l}\text { Eavironmental } \\
\text { and ambient }\end{array}$ & Sky, ground, sun, fire, water, day, night \\
\hline $\begin{array}{l}\text { Life forms and } \\
\text { related words }\end{array}$ & Grow (in the ground, creature, bird, fish, tree, egg \\
\hline Materials & Wood, stone \\
\hline $\begin{array}{l}\text { Actions and } \\
\text { activities }\end{array}$ & Hoki, make, play, kill, laugh, sing \\
\hline Manner & Quickly, slowly \\
\hline
\end{tabular}

Sumber: Goddard, 2008 dan Niputu, 2015

Ketiga, polisemi menurut metabahasa semantik alami merupakan bentuk leksikal tunggal yang dapat mengekspresikan dua makna asali yang berbeda. Hal ini terjadi karena adanya hubungan komposisi antara eksponen yang satu dengan eksponen yang lain. Karena eksponen tersebut memiliki kerangka gramatikal yang berbeda.Ada dua hubungan nonkomposisi yang paling kuat, yakni hubungan pengartian (entailment-like relationship) dan hubungan implikasi (implikasional) (Wierzbicka, 1996 dalam Mulyadi, 2006: 71).Keempat, sintaksis makna universal yang dikembangkan oleh Wierzbicka pada tahun 1970-an.Wierzbicka mengatakan bahwa makna memiliki struktur yang sangat kompleks, dan tidak hanya dibentuk dari elemen sederhana, seperti seseorang, ingin, dan tahu dari komponen berstruktur kompleks.Sintaksis universal terdiri atas kombinasi leksikon butir makna asali universal yang membentuk proposisi sederhana sesuai dengan perangkat morfosintaksis.Misalnya ingin memiliki kaidah universal tertentu dalam konteks "saya ingin melakukan ini".Unsur dasar sintaksis universal dapat disamakan dengan sebuah kalusa yang dibentuk oleh substantif, predikat, dan beberapa elemen tambahan yang diperlukan oleh predikatnya.Kombinasi elemen-elemen ini akan membentuk sintaksis universal yang menurut teori MSA, disebut dengan "kalimat kanonis", yaitu konteks tempat leksikon asal diperkirakan muncul secara universal.

\section{METODE PENELITIAN}

Tahapan dalam penelitian ini, yaitu mengumpulkan data, analisis data, dan penyajian hasil analisis data.Data penelitian ini dikumpulkan dengan menggunakan metode simak dan metode cakap (Sudaryanto, 1993:13). Dalam metode cakap dilakukan dengan cara mewawancarai narasumber, sedangkan dalam metode simak menggunakan teknik lanjutan berupa teknik simak libat cakap, yaitu terlibat secara langsung dalam dialog dengan narasumber dan merekam topik pembicaraan (Sudaryanto, 1993: 133).Setelah data dikumpulkan, 
data itu dikelompokkan berdasarkan kategori, tempat, penampilan, tujuan, dan ukuran.

Dalam analisis data digunakan metode padan dan metode agih.Metode padan diterapkan untuk mengidentifikasi butir leksikal yang secara intuitif tergolong ke dalam peralatan dapur untuk menetapkan kategorisasinya.Butir leksikal yang termasuk ke dalam peralatan dapur tersebut akan dikumpulkan dan selanjutnya dikelompokkan berdasarkan ciri semantisnya.Misalnya, kudin gelang-gelang 'periuk kuningan', kudin taneh 'periuk tanah', lagan 'cobek', dan sangkalen 'talenan' mengacu pada substantif relasional, yaitu "substantif relasional PERALATAN DAPUR yang menghidangkan makanan".Metode agih berperan dalam menganalisis dan membandingkan makna.Teknik analisis yang digunakan adalah teknik ganti untuk menguji makna peralatan dapur dan teknik perafrase untuk menentukan makna.Misalnya untuk mengetahui makna pinggan 'piring (kecil)' dan capah 'piring (besar)'.Hasil analisis data disajikan dengan metode formal dan informal.Metode penyajian formal perumusan dengan tanda dan lambang-lambang.Metode informal perumusan dengan kata-kata biasa(Sudaryanto, 1993:145).

\section{HASIL DAN PEMBAHASAN}

\section{A. Kategorisasi Peralatan Dapur}

Kategorisasi peralatan dapur dalam kajian ini dibedakan menjadi tiga.Pertama, peralatan dapur yang digunakan untuk mengolah. Peralatan dapur yang digunakan untuk mengolah dibedakan menjadi dua subkategori, yaitu peralatan dapur yang digunakan untuk mengolah makanan seperti, renceng 'sejenis periuk', sangkalen 'talenan', lagan 'cobek', lesung 'lesung', kudin taneh 'periuk tanah', kudin gelang-gelang 'periuk kuningan' dan minuman seperti, renceng 'sejenis periuk'. Kedua, peralatan dapur yang digunakan untuk menyimpan. Peralatan dapur yang digunakan untuk menyimpan dibedakan menjadi tiga subkategori, yaitu peralatan dapur untuk menyimpan makanan seperti, gumbar 'sejenis rantang', abal-abal 'tabung dari bambu', ingan cina 'tempat bumbu', perakan 'tempat nasi', busan 'sejenis perian, caduken 'sejenis tabung dari bambu'. Peralatan masak, dan menyimpan air seperti, kuran 'perian', guci 'buyung', tambe 'perian', ingan minem 'cangkir', botol ingan minem 'teko',tabu-tabu 'kandi', kitang 'tempat minum', kandi-kandi 'bumbung', kendi 'tempat minum dari tembaga'. Dan peralatan dapur yang digunakan untuk menyimpan peralatan dapur seperti, para ganjang 'para atas', kerpei 'rotan yang dianyam berbentuk cincin', ketang 'rotan', para tuhur 'para bagian bawah'. Ketiga, peralatan dapur yang digunakan untuk menghidangkan makanan misalnya, pinggan 'piring kecil',capah'piring besar, pinggan. Untuk lebih jelasnya dapat dilihat pada bagan di bawah ini. 


\section{Bagan 1}

\section{Komponen Semantis PeralatanDapur dalam Bahasa Karo}

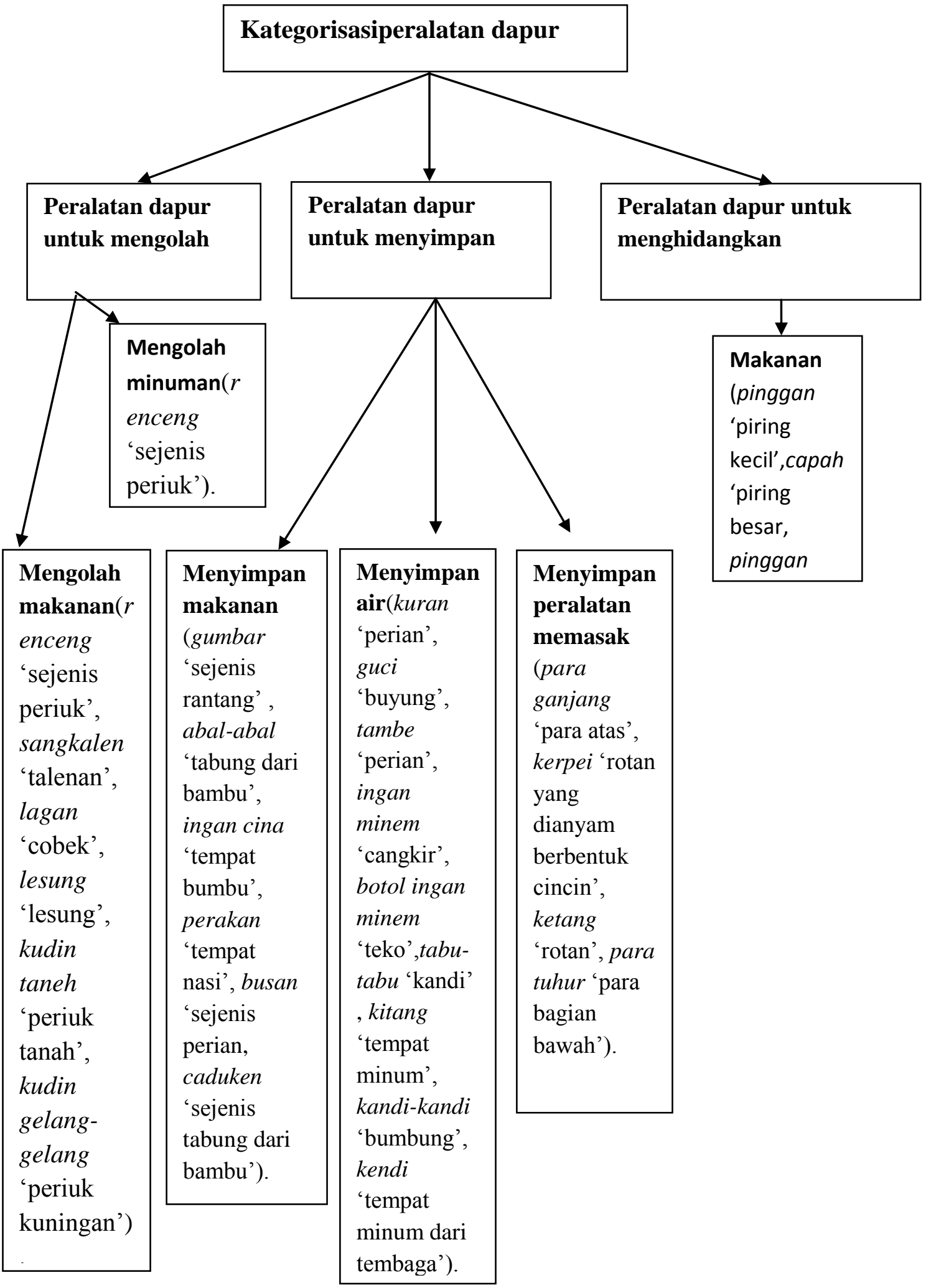

Peralatan dapur yang digunakan untuk mengolah peralatan, menyimpan, dan menghidangkan memiliki ciri utama yang membedakan ketiganya.Hal ini 
dapatdigambarkan dengan komponen semantis peralatan dapur pada tabel di bawah ini.

Tabel 3

Komponen Semantis Peralatan Dapur dalam Bahasa Karo

\begin{tabular}{|l|l|l|}
\hline $\begin{array}{l}\text { Peralatan Dapur } \\
\text { untuk Mengolah }\end{array}$ & $\begin{array}{l}\text { Peralatan Dapur untuk } \\
\text { Menyimpan }\end{array}$ & $\begin{array}{l}\text { PelaratanDapur } \\
\text { untuk Menghidangkan }\end{array}$ \\
\hline $\begin{array}{l}\text { Salah satu jenis } \\
\text { benda }[\mathrm{M}]\end{array}$ & $\begin{array}{l}\text { Salah satu jenis } \\
\text { benda }[\mathrm{M}]\end{array}$ & Salah satu jenis benda $[\mathrm{M}]$ \\
\hline $\begin{array}{l}\text { Digunakan untuk } \\
\text { mengolah }[\mathrm{M}] \\
\text { sesuatu }\end{array}$ & $\begin{array}{l}\text { Digunakan untuk } \\
\text { menyimpan }[\mathrm{M}] \\
\text { sesuatu }\end{array}$ & $\begin{array}{l}\text { Menghidangkan }[\mathrm{M}] \\
\text { sesuatu }\end{array}$ \\
\hline $\begin{array}{l}\text { Benda ini berada di } \\
\text { tempat oranghidup }[\mathrm{M}]\end{array}$ & $\begin{array}{l}\text { Benda ini berada } \\
\text { di tempat orang hidup }[\mathrm{M}]\end{array}$ & $\begin{array}{l}\text { Benda ini berada } \\
\text { di tempat orang hidup }[\mathrm{M}]\end{array}$ \\
\hline $\begin{array}{l}\text { Benda inimungkin } \\
\text { besar/kecil }[\mathrm{M}]\end{array}$ & $\begin{array}{l}\text { Benda ini mungkin } \\
\text { besar/kecil }[\mathrm{M}]\end{array}$ & $\begin{array}{l}\text { Benda ini mungkin besar/ } \\
\text { Kecil[M] }\end{array}$ \\
\hline $\begin{array}{l}\text { Seseorang berpikir benda } \\
\text { initerbuat dari batu } \\
\text { atau tembaga }[\mathrm{M}]\end{array}$ & $\begin{array}{l}\text { Seseorangberpikir benda } \\
\text { ini terbuat dari batu, kayu } \\
\text { atau bambu }[\mathrm{M}]\end{array}$ & $\begin{array}{l}\text { Seseorang berpikir benda } \\
\text { ini terbuat dari batu, } \\
\text { bambu, dan kayu } \\
{[\mathrm{M}]}\end{array}$ \\
\hline
\end{tabular}

\section{B. Makna Peralatan Dapur}

Makna peralatan dapur yang digunakan untuk mengolah dibedakan menjadi tiga seperti pada tabel di bawah ini.

Tabel 4

Peralatan Dapur yang Digunakan untuk Mengolah

\begin{tabular}{|c|c|c|}
\hline $\begin{array}{l}\text { Peralatan Dapur yang } \\
\text { Digunakan } \text { untuk } \\
\text { Mengolah Makanan } \\
\text { dan Minuman }\end{array}$ & $\begin{array}{l}\text { Peralatan Dapur yang } \\
\text { Digunakan untuk } \\
\text { Menghidangkan } \\
\text { Makanan }\end{array}$ & $\begin{array}{l}\text { Peralatan Dapur yang } \\
\text { Digunakan untuk } \\
\text { Menghidangkan } \\
\text { Makanan }\end{array}$ \\
\hline $\begin{array}{l}\text { sangkalen 'talenan', } \\
\text { lagan 'cobek', lesung } \\
\text { 'lesung', kudin taneh } \\
\text { 'periuk tanah', kudin } \\
\text { gelang-gelang 'periuk } \\
\text { kuningan', } \\
\text { 'parutan', para tuhur } \\
\text { 'para bagian bawah'. } \\
\text { sekin'parang' dan belati } \\
\text { 'pisau', dan renceng } \\
\text { 'sejenis periuk.' }\end{array}$ & $\begin{array}{lr}\text { pinggan 'piring (kecil)', } & \\
\text { campah 'piring (besar)', } \\
\text { pinggan pasu 'piring } \\
\text { (besar)' ukat 'sendok } \\
\text { nasi', ukat gulen } \\
\text { 'sendok sayur' }\end{array}$ & $\begin{array}{l}\text { gumbar 'sejenis } \\
\text { rantang', abal-abal } \\
\text { 'tabung dari bambu', } \\
\text { ingan cina 'tempat } \\
\text { bumbu', 'tempat nasi', busan } \\
\text { 'sejenis perian', caduken } \\
\text { 'sejenis tabung dari } \\
\text { bambu', kuran 'perian', } \\
\text { guci 'buyung', tambe } \\
\text { 'perian', ingan minem } \\
\text { 'cangkir', botol ingan } \\
\text { minem 'teko' tabu- }\end{array}$ \\
\hline
\end{tabular}




\begin{tabular}{|l|l|}
\hline & tabu'kandi, kitang \\
& 'tempat minum', kandi- \\
& kandi 'bumbung', kendi \\
'tempat minum dari \\
tembaga', paraganjang \\
'para atas', kerpei 'rotan \\
yang dianyam berbentuk \\
cincin', ketang 'rotan', \\
dan para tuhur 'para \\
bagian bawah'
\end{tabular}

Butir leksikal di atas memiliki fitur semantis khusus yang membedakan satu butir leksikal dengan butir leksikal yang lain. Untuk memperlihatkan perbedaan halus yang terdapat dalam satu butir leksikal akan dilakukan dengan teknik parafrase. Peralatan dapur yang digunakan untuk megolah berkolerasi dengan komponen “ BENDA INI ADA KARENA SESEORANG INGIN MENGOLAH [M] SESUATU.' Misalnya, Makna peralatan dapur yang mengacu pada mengolah makanan dan minuman menyangkut subkategori 'benda $[\mathrm{M}]$ ini ada karena seseorang ingin mengolah makanan $[\mathrm{M}]$, benda $[\mathrm{M}]$ ini berada di tempat orang hidup, benda $[\mathrm{M}]$ ini mungkin besar/kecil $[\mathrm{M}]$, dan seseorang mungkin berpikir benda ini terbuat dari besi, tanah, batu, atau tembaga [M].' Misalnya kudin gelang-gelang 'periuk kuningan', kudin taneh 'periuk tanah'. Ketiga butir leksikal tersebut berada dalam satu ranah semantis yang sama, tetapi memiliki perbedaan halus antara ketiga butir leksikal tersebut. Contoh:

a. Nangger nakan kaka salu kudin gelang-gelang/?kudin taneh.

Masak nasi TG pakai periuk kuningan/? Periuk tanah.

'Kakak memasak nasi dengan periuk kuningan/ ?periuk tanah'.

b. Nangesken nurung kaka salu?kudin gelang-gelang/kudin taneh

Mengarsik ikan mas TG pakai ?periuk kuningan/ periuk tanah

'Kakak mengarsik ikan mas dengan ?periukkuningan/ periuk tanah'.

Kudin gelang-gelang 'periuk kuningan' digunakan untuk mengolah atau memasak nasi, sedangkan kudin taneh 'periuk tanah' digunakan untuk mengolah atau memasak ikan dan sayur. Selanjutnya untuk mengetahui perbedaan halus yang terkandung pada kudin gelang-gelang 'periuk kuningan', dan kudin taneh 'periuk tanah' dilakukan parafrase makna seperti di bawah ini:

kudin gelang-gelang 'periuk kuningan'

a. Salah satu jenis benda [M]

b. Benda [M] ini ada karena seseorang membuatnya

c. Benda ini berada di atas kerpei 'rotan yang dianyam berbentuk cincin'

d. Seseorang menginginkan benda [M] ini karena seseorang ingin MEMASAK NASI

e. Seseorang ingin MEMASAK NASI karena seseorang tidak ingin terjadi sesuatu yang buruk pada seseorang

f. Benda [M] ini terbuat dari KUNINGAN 
g. Benda [M] ini memiliki TUTUP]

h. Benda [M] ini berwarna KUNING

i. Benda [M] ini KECIL

j. Seseorang mengambilnya dengan dua tangan

kudin taneh 'periuk tanah'

a. Salah satu jenis benda [M]

b. Benda [M] ini ada karena seseorang membuatnya

c. Benda [M] ini berada di atas kerpei 'rotan yang dianyam berbentuk cincin

d. Seseorang menginginkan benda [M] ini karena seseorang ingin MEMASAK IKAN DAN SAYUR.

e. Seseorang ingin orang lain dapat MEMASAK IKAN DAN SAYUR karena seseorang tidak ingin terjadi sesuatu yang buruk pada orang itu [M]

f. Benda [M] ini terbuat dari TANAH

g. Benda [M] ini memiliki tutup seperti MANGKUK Benda [M] ini memiliki badan yang lebih lebar daripada [M] bagian atas

h. Benda [M] ini berwarna COKELAT

i. Benda [M] ini KECIL

$j$. Seseorang mengambilnya dengan dua tangan

Untuk memperlihatkan secara lebih jelas perbedaan semantis yang terdapat pada kudin gelang-gelang 'periuk kuningan' dan kudin taneh 'periuk tanah' dapat dilihat pada tabel di bawah ini:

Tabel 5

Perbedaan Semantis Kudin Gelang-Gelang'Periuk Kuningan’ danKudin Taneh'Periuk Tanah'

\begin{tabular}{|l|l|l|l|l|l|}
\hline $\begin{array}{l}\text { Nama } \\
\text { peralatan } \\
\text { dapur }\end{array}$ & Kategori & Tempat & Tujuan & Penampilan & Ukuran \\
\hline $\begin{array}{l}\text { Kudin } \\
\text { gelang- } \\
\text { gelang } \\
\text { 'periuk } \\
\text { kuningan' }\end{array}$ & $\begin{array}{l}\text { Salah satu } \\
\text { jenis } \\
\text { peralatan } \\
\text { dapur [M]. }\end{array}$ & $\begin{array}{l}\text { Di atas kerpei } \\
\text { 'rotan yang } \\
\text { dianyam } \\
\text { berbentuk } \\
\text { cincin' }\end{array}$ & $\begin{array}{l}\text { Memasak } \\
\text { nasi }\end{array}$ & $\begin{array}{l}\text { Terbuat dari } \\
\text { kuningan, } \\
\text { berwarna } \\
\text { kuning, dan } \\
\text { memiliki } \\
\text { tutup. }\end{array}$ & Kecil \\
\hline $\begin{array}{l}\text { Kudin } \\
\text { taneh } \\
\text { 'periuk } \\
\text { tanah' }\end{array}$ & $\begin{array}{l}\text { Salah satu } \\
\text { jenis } \\
\text { peralatan } \\
\text { dapur [M]. }\end{array}$ & $\begin{array}{l}\text { Di atas kerpei } \\
\text { 'rotan yang } \\
\text { dianyam } \\
\text { berbentuk } \\
\text { cincin' }\end{array}$ & $\begin{array}{l}\text { Memasak } \\
\text { ikan dan } \\
\text { sayur }\end{array}$ & $\begin{array}{l}\text { Terbuat } \\
\text { dari tanah, } \\
\text { berwarna } \\
\text { coklat, dan } \\
\text { tidak } \\
\text { memiliki } \\
\text { tutup. }\end{array}$ & Kecil \\
\hline
\end{tabular}

Model aplikasi yang lain adalah makna peralatan dapur yang digunakan untuk menyimpan peralatan dapur dibedakan menjadi tiga, yaitu pertama, peralatan dapur yang menyimpan makanan. Butir leksikalnya adalah gumbar 'sejenis rantang', abal-abal 'tabung dari bambu', pernakan 'tempat nasi dan 
beras', dan ingan cina 'tempat bumbu', busan 'sejenis perian' caduken 'sejenis tabung dari bambu', dan para tuhur 'para bawah'. Kedua, peralatan dapur yang menyimpan air. Butir leksikalnya kuran 'perian', guci 'buyung' tambe 'perian', ingan minem 'cangkir', botol ingan minem 'teko', tabu-tabu 'kendi', kitang 'tempat minum', dan kandi-kandi 'bumbung', dan kendi 'tempat air dari tembaga'. Ketiga, peralatan dapur yang menyimpan peralatan masak, yaitu para ganjang 'para bagian atas', kerpei 'rotan yang dianyam berbentuk cincin', dan ketang 'rotan'. Butir leksikal yang terdapat dalam kategori di atas memiliki fungsi yang sama, tetapi setiap butir leksikal memiliki ciri semantis yang membedakannya dengan butir leksikal yang lain hal ini akan dilakukan dengan teknik parafrase. Hal ini berkolerasi dengan komponen "BENDA [M] INI ADA KARENA SESEORANG INGIN MENYIMPAN SESUATU'.Gumbar 'sejenis rantang', abal-abal 'tabung dari bambu', dan caduken 'sejenis tabung dari bambu' berada dalam satu ranah yang sama, tetapi ketiga butir leksikal tersebut memiliki perbedaan makna yang sangat halus. Perhatikan kalimat berikut.

a. Tama nande beltu-beltuku bas abal-abal/?gumbar/??caduken.

'Ibu menaruh daging yang sudah kering ke dalam tabung dari bambu ?sejenis rantang/?? sejenis tabung dari bambu'.

b.Tama nande sira ku bas gumbarl?abal-abal/??caduken.

'Ibu menaruh garam ke dalam tabung dari bambu ?sejenis rantang/?? sejenis tabung dari bambu'.

c.Tama nande nurung ku bascaduken/?abal-abal/??gumbar.

'Ibu menaruh ikan mas ke dalam sejenis tabung dari bambu/?sejenis rantang/?? sejenis tabung dari bambu'.

Abal-abal 'tabung dari bambu' biasanya digunakan untuk tempat daging yang sudah keringgumbar 'sejenis rantang' biasanya digunakan sebagai tempat menyimpan garam caduken'sejenis tabung dari bambu' digunakan sebagai tempat menyimpan ikan. Untuk memperlihatkan ciri semantis yang terdapat dalam abal-abal, gumber, dan caduken dilakukan parafrase makna seperti di bawah ini:

abal-abal 'tabung dari bambu'

a.Salah satu jenis benda [M]

b.Benda [M] ini ada karena seseorang membuatnya

c.Benda [M] ini di letakkan di dekat TUNGKU

d.Seseorang memuat benda [M] ini karena seseorang ingin MENYIMPAN

$D A G I N G$

e. Seseorang ingin MENYIMPAN DAGING karena seseorang tidak ingin terjadi

sesuatu yang buruk (busuk)

f. Benda [M] ini berbentuk tabung

g.Benda [M] ini memiliki TALI pada BAGIAN ATAS

h.Benda [M] ini terbuat dari bambu

i. Benda [M] ini besar

j. Seseorang mengambilnya dengan dua tangan [M] 
gumbar'sejenis rantang'

a.Salah satu jenis benda [M]

b.Benda [M] ini ada karena seseorang membuatnya

c. Benda [M] ini diletakkan di samping TUNGKU [M]

d.Seseorang membuat benda [M] ini karena seseorang ingin TEMPAT GARAM

e. Seseorang ingin menyimpan GARAM [M] karena seseorang tidak ingin terjadi sesuatu yang buruk [M]

f. Benda [M] ini berbentuk MANGKUK [M]

g.Benda [M] ini memiliki tutup yang menpunyai DUA TALI di sebelah kiri dan kanan

h.Benda [M] ini terbuat dari bambu

i. Benda [M] ini KECIL

j. Seseorang mengambilnya dengan satu tangan

caduken 'sejenis tabung dari bambu'

a.Salah satu jenis benda [M]

b.Benda [M] ini ada karena seseorang membuatnya

c. Benda ini biasanya diletakkan di ATAS PARA BAGIAN BAWAH

d.Seseorang menginginkan benda [M] ini karena seseorang ingin MENYIMPAN IKAN [M]

e.Seseorang ingin MENYIMPAN IKAN karena seseorang tidak ingin terjadi sesuatu yang buruk (busuk)

f. Benda [M] ini berbentuk TABUNG

g.Benda [M] ini terbuat dari satu ruas bambu

h.Benda [M] ini besar

i. Seseorang mengambilnya dengan dua tangan

\section{KESIMPULAN}

Teori MSA menggunakan konsep makna asal, polisemi, makna asali, dan sintaksis makna universal.Konsep tersebut bertujuan membatasi makna kata dengan teknik parafrase.Melalui perangkat makna asali perbedaan makna pada setiap kata yang memiliki ciri semantis yang sangat dekat dapat diungkapkan secara jelas.Hal ini sangat penting bagi para linguis untuk dapat memahami perbedaan halus yang terdapat pada makna kata secara jelas dan nyata.Analisis peralatan dapur dalam bahasa Karo dibagi menjadi tiga kategori, yaitu peralatan dapur yang digunakan untuk menyimpan, menghidangkan, dan menyimpan makanan dan minuman. Ketiga kategori tersebut dibentuk oleh elemen makna asali SESUATU, KARENA, SESEORANG, ADA, INGIN, dan MELAKUKAN.

\section{SARAN}

Analisis nomina dalam kajian metabahasa semantik alami (MSA) masih sangat sedikit dikaji oleh para linguis.Kajian metabahas semantik alami pada umumnya dikaji para peneliti dalam cakupan verba oleh karena itu, penulis menyarankan supaya lebih banyak lagi kajian nomina yang dianalisis.Dalam keterbatasan bahan kajian ini masih ada kekurangan oleh karena itu diharapkan kekurangan itu diperbaiki oleh peneliti berikutnya. 


\section{DAFTAR PUSTAKA}

Sudaryanto. 2015. Metode dan Aneka Teknik Analisis Bahasa. Yogyakarta: Duta Wacana University Press.

Ardianta, Andi Setya. 2013. "Bahasa Jawa Usia Anak-Anak Kajian Metabahasa Semantik Alami Di TK Al Hidayah V Kwarasan Grogol Sukoharjo" (Skripsi). Fakultas Keguruan Surakarta

Sentosa. 2013. "Analisis Semantik Sinonim Tomidachi, Yuujin, dan Nakama dalam Kalimat Bahasa Jepang" (Skripsi). Fakultas Keguruan dan Ilmu Pendidikan. Universitas Riau.

Septiani, Renny . 2011. "Tipe Semantis Komponen Makna Nomina Bahasa Indonesia dalam Antologi Cerpen Jakarta Kafe Karya Tatyana" (Skripsi). Fakultas Pendidikan Bahasa dan Sastra, Universitas Pendidikan Indonesia

Wijaya R, Gede Primahadi. 2011. "Polisemi pada Leksem Head Tinjauan Linguistik Kognitif". Program Pascasarjana, Universitas Udayana

Mulyadi dan Rumnasari K.Siregar. 2010. "Aplikasi Teori Metabahasa Semantik Alami dalam Kajian Makna". Logat, 11 (2): 69-75.

Utami, Ratno. 2010. "Kajian Sinonim Nomina dalam Bahasa Indonesia”. Program Pasca Sarjana, Universitas Sebelas Maret

Arwana, Nengah. 2006. "Bahasa Bali Usia Anak-Anak Kajian Metabahasa Semantik Alami”. Linguistika, 16 (30): 1-19

Goddard, Cliff.2006. "Semantic Molecules”.Diakses Tanggal 21 Maret 2016. Tersedia dari: https://www.google.co.id/url?sa=t\&source=web\&rct=j\&url=http://www98.griffi th.edu.au/despace/bitstream/handle/10072/46996/78558_1

Prinst, Darwin. 2002. Kamus Karo Indonesia. Medan: Bina Media

Goddard, Cliff. 1998. Semantic Analysis. England: Oxford University Press.

Wierzbicka, Anna. 1996. Semantis Primes and Universals. New York: Oxford University Press. 